\title{
The Impact of Recast versus Prompts on the Grammatical Accuracy of Iranian EFL Learners' Speech
}

\author{
Azar Hosseini Fatemi \\ English Department, Faculty of Letters and Humanities, Ferdowsi University of Mashhad, Iran \\ Nazar Ali Harati (Corresponding author) \\ English Department, Ferdowsi University of Mashhad, International Branch, Mashhad, Iran
}

\begin{abstract}
This quasi-experimental study, conducted in English-as-a-foreign-language (EFL) classrooms at the university level in Iran, is aimed at investigating whether corrective feedback (CF) could enhance grammatical accuracy in the learners' speech; and if it could, which type of $C F$ is more effective than the other one. The 96 participants of the study, who were selected out of 169 freshmen students on the basis of a written pretest, took a picture description test the results of which were the criterion for their random divisions into three homogeneous groups. Whenever language learners in two experimental groups made any grammatical errors during the study, consistent CF, recast for one group and prompts for the other one, was provided for them and students in the third group, who functioned as the control group, received no CF for their morphosyntactic errors. Analysis of the results in the posttest revealed significant differences between the two CF groups and the control group on the one hand and between the recast and the prompts groups on the other hand. These results suggested that though the provision of two CF types significantly increased accuracy in the use of present forms of the verb 'to be' and the syntactic agreement associated with ' $-\mathrm{s}$ inflection', the remarkable outperformance of students in the prompts group over the other two groups indicated the relative efficacy of this type of CF.
\end{abstract}

Index Terms - focus on form, recast, prompts, grammatical accuracy

\section{INTRODUCTION}

$\mathrm{CF}$, defined as "the feedback that learners receive on the linguistic errors they make in their oral or written production in a second language (L2)", has fascinated scholars, researchers and language teachers in recent years because of its "significance for the development of theories of L2 acquisition" and the important role it plays "in L2 pedagogy" (Sheen and Ellis, 2011, p. 593). The growing attention to CF emanates from the theoretical turning points that took place within L2 pedagogy in 1980s when Krashen's (1982) Input Hypothesis, with the assumption that the provision of comprehensible input in an affectively non-threatening environment would make language acquisition inevitable, convinced some advocates of communicative approach to recommend that language teachers should say farewell to what Long (1991) termed focus-on-forms (FonFs) in their classrooms. Besides, CF was also deemed to be unnecessary both in strong and weak version of this Hypothesis (VanPatten and Benati, 2010). However, the implementation of Krashen's ideas in Canadian immersion programs were not very satisfactory and studies revealed that language learners' productive skills, after years of receiving sufficient comprehensible input, were not comparable to those of native speakers in terms of accuracy (Harley \& Swain, 1984; Lightbown and Spada, 1990). Therefore, the widespread outcry 'against comprehensible input' (White, 1987; McLaughlin, 1987) culminated in the emergence of some theoretical and pedagogical remedies in which CF lends a helping hand, namely Long's $(1983,1996)$ Interaction Hypothesis, Swain's (1985) Output Hypothesis and Schmidt's (1990) Noticing Hypothesis as well as form-focused instruction (FFI) (Lightbown and Spada, 1990; Long, 1991).

Long's (1991) distinction between focus-on-form (FonF) instruction, which "overtly draws students' attention to linguistic elements as they arise incidentally in lessons whose overriding focus is on meaning or communication" (pp. 45-6), and the traditional FonFs instruction, which "always entails isolation or extraction of linguistic features from context or from communicative activity" (Doughty \& Williams, 1998, p. 3) seemed convincing enough for a number of scholars, researchers and practitioners to jump on the bandwagon of FFI to put an end to form-meaning imbalances in learners' outputs within communicative approach since it was considered to enable a language learner to (1) notice "a form/word for the first time in the input, potentially leading to a conversion to intake", (2) notice "that an IL [Interlanguage] form is at odds with the TL [target language] input ("the gap"), leading to destabilization of that form", and/"or" (3) incorporate "a new form into the developing IL" (Williams, 2005, p. 686). Hence, CF, as a reactive approach to FFI, became the apple of researchers' eyes once again after a decade during which studies on CF had 
waned because of the advent of communicative language teaching (CLT) which was under the influence of Input Hypothesis (Spada, 2013).

Not long after the birth of FFI, controversies over the possible CF strategies to be implemented in FFI to resolve form-meaning imbalances in communicative approach grew. In an oft-cited paper, Lyster and Ranta (1997) opened up the Pandora's box of CF strategies and cast serious doubt on the efficacy of 'recasting' as the only remedy at language teachers' disposal. That is, their findings revealed that recasting, which was the most widely used CF by the teachers in Canadian immersion programs, was the least successful technique in stimulating learners to respond to this type of feedback and four other types of feedback, called prompts, were much more effective in pushing learners of their study to self repair, namely 'elicitation', 'clarification requests', 'metalinguistic feedback', and 'repetition' in a descending order. Most of other research studies conducted on CF types have focused on recast so far and their results indicate that its provisions are more noticeable for learners when phonological and lexical errors are the main targets rather than morphosyntactic errors (Carpenter et al., 2006; Ellis et al., 2001; Han, 2008; Lyster, 1998; Mackey et al., 2000; Sheen, 2006).

Some scholars have underscored the need for empirical studies to target two questions: "(a) which grammatical structures are most amenable to CF and (b) whether recasts and prompts have differential effects on different kinds of grammatical structures" (Yang \& Lyster, 2010, p. 240). Ellis (2007, p. 360), for example, suggests that "what is needed in future research is to determine how linguistic factors may determine when different types of feedback will work for acquisition" or Sheen (2011, p. 165) points out that "we cannot assume that because CF has been shown to assist the acquisition of one grammatical feature it will necessarily do so for all features". Therefore, as indicated in a recent review of studies on oral $\mathrm{CF}$, this call for conducting studies to examine the efficacy of $\mathrm{CF}$ in accuracy development has been welcomed by some researchers and examples of a few grammatical features that have been examined in various settings and languages are "questions, passive forms, past tense, articles, and possessive determiners in English; gender attribution and noun-adjective agreement in French; adverb placement, object topicalization, and gender agreement in Spanish; aspectual forms, adjective ordering, and locative constructions in Japanese" (Lyster et al., 2013, p. 22). This study aims to examine the impact of provision of recast in comparison with that of prompts on the grammatical accuracy of Iranian EFL learners' speech. More specifically, it focuses on accuracy development in the use of present forms of the verb 'to be' and the syntactic agreement associated with '-s inflection'.

\section{LITERATURE REVIEW}

\section{A. Types of Oral CF}

Based on a labyrinthine taxonomy put forward by Sheen and Ellis (2011), oral CF can be classified into two broad categories of 'input-providing' and 'output-prompting'. While the techniques in the former (i.e., conversational recasts, didactic recasts, explicit correction only and explicit correction with metalinguistic explanation) are used to provide correct form to the learner, the latter contains a set of strategies that withhold correct form (i.e., repetition, clarification request, metalinguistic clue, elicitation, paralinguistic signal) and are means to push learners toward self- or peer correction. CF strategies in each category are further divided in terms of whether they are implicit or explicit. That is, conversational recasts within input-providing category as well as repetition and clarification request among outputprompting CF strategies are considered implicit and the rest are classified as explicit. Table 1 summarizes the taxonomy of oral CF strategies along with their definitions.

TABLE 1.

A TAXONOMY OF ORAL CF STRATEGIES (ADAPTED FROM SHEEN \& ELLIS, 2011, P. 594)

\begin{tabular}{|l|l|l|}
\hline & Implicit & Explicit \\
\hline Input-providing & $\begin{array}{l}\text { - Conversational recasts (i.e., the correction consists of a } \\
\text { reformulation of a student utterance in the attempt to } \\
\text { resolve a communication problem; such recasts often take } \\
\text { the form confirmation checks where the reformulation is } \\
\text { followed by a question tag as in "Oh, so you were sick, } \\
\text { were you?"). }\end{array}$ & $\begin{array}{l}\text { - Didactic recasts (i.e., the correction takes the form of a } \\
\text { reformulation of a student utterance even though no } \\
\text { communication problem has arisen). } \\
\text { - Explicit correction only (i.e., the correction takes the form } \\
\text { of a direct signal that an error has been committed and the } \\
\text { correct form is supplied). } \\
\text { - Explicit correction with metalinguistic explanation (i.e., in } \\
\text { addition to signaling an error has been committed and } \\
\text { providing the correct form, there is also a metalinguistic } \\
\text { comment). }\end{array}$ \\
\hline Output-prompting & $\begin{array}{l}\text { - Retalinguistic clue (i.e., a brief metalinguistic statement } \\
\text { repeated without any intonational highlighting of the } \\
\text { error). } \\
\text { - Clarification requests (i.e., attention is drawn to a } \\
\text { problem utterance by the speaker indicating he/she has not } \\
\text { understood it). }\end{array}$ & $\begin{array}{l}\text { - Elicitation (i.e., an attempt is made to verbally elicit the } \\
\text { correct form from the learner by, for example, a prompting } \\
\text { question). } \\
\text { - Paralinguistic signal (i.e., an attempt is made to non- } \\
\text { verbally elicit the correct form from the learner). }\end{array}$ \\
\hline
\end{tabular}

\section{B. The Role of CF in Second Language Acquisition}


Ellis (1997) argues that acquisition can be considered as the internalization of new forms or as an increase in control over forms that have already been internalized. This distinction might shed some light on a number of empirical studies conducted on CF and resolve some controversies that have lingered on since Lyster and Ranta's (1997) seminal paper. As noted above, recasts and prompts are distinguished from each other in terms of whether they are input-providing $\mathrm{CF}$ (supplies the correct reformulation) or output-pushing CF (withholds the correct reformulation and encourages learners to self-repair). The former tends to engage learners in cognitive comparison in the working memory (Ellis, 1994) and the latter might encourage learners to retrieve information from long-term memory. Therefore, while recasts may pave the way for the internalization of new forms, prompts seem to boost control over forms that have already been internalized since they might provide an opportunity for the learners to revise or restructure their partially internalized forms.

Some scholars interested in the acquisition of new knowledge have advocated the provision of conversational recasts in cases a communication problem arises because such input-providing CF is believed not to break the flow of communication and helps make input more comprehensible and thereby promote acquisition (Long, 1983). Hence, drawing upon Noticing Hypothesis which underscores the importance of conscious noticing for the input to be turned into intake (Schmidt, 1990), some researchers have used this type of CF as a tool to verify its effectiveness in their empirical studies on FFI (e.g., Doughty, 2001; Doughty \& Williams, 1998; Long \& Robinson, 1998).

However, this type of implicit $\mathrm{CF}$ has not been immune to criticism. First, inconsistencies in operational definitions of recasts in various studies, which have made Ellis \& Sheen (2006) to compare recasts to a chameleon, have almost resulted in incomparability of the results of a number of studies which tend to look at the same thing through different perspectives (Nicholas et al. 2001). Second, it has been argued that implicit recasts can be ambiguous since learners might conceive them as signs of approval rather than negative feedback (Lyster, 1998; Lyster, 2004) which, in turn, may make it difficult to draw learners' attention to form in FFI (Musumeci, 1996; Pica, 2002; Tomasello \& Herron, 1989). As a reaction to the second criticism, some researchers have tried to make recasts more explicit through the use of rising intonation to signal the error clearly (Doughty \& Varela, 1998; Erlam \& Loewen, 2010). In Doughty \& Varela's (1998) study, for instance, the teacher repeated the student's erroneous utterance and made use of stress and rising intonation to draw learners' attention and if the learner did not respond to such CF, the teacher provided a recast in which the verb form was stressed. However, as Lyster \& Mori (2006, p. 276) point out, since "the teacher consistently used repetition to draw attention to the error and then used recasts only when students made no attempt at repair, the study provides more support for prompting techniques than for recasting".

Looking at the other side of the acquisition coin, Lyster et al. (2013, p. 13) assert that "the ultimate goal of instruction is not to continuously present only new knowledge to students, without providing enough subsequent opportunities for assimilation and consolidation of that knowledge". Therefore, they underscore the possibilities that prompts can provide for language learners to "retrieve and restructure their knowledge of the target language". Prompts are justified on the basis of Swain's (1985) Output Hypothesis which posits that the production of language facilitates pinpointing the gap between one's interlanguage and the target language. That is, output triggers noticing which, in turn, might result in its modification. Therefore, the efficacy of output-prompting CF has been investigated in light of this cognitive processing (e.g., Ammar \& Spada, 2006; Lyster, 2004; McDonough, 2005). Furthermore, skill-acquisition theory (Anderson, 1983, 2005; Johnson, 1996) is considered to give a green light to the provision of prompts too. That is, since repeated practice is claimed to play a major role in changing the declarative knowledge into procedural one (Dekeyser, 1998, 2001), prompts are considered to be "effective both for developing accurate knowledge by restructuring their already existing knowledge and for enhancing the practice effect by pushing" the learners to self-repair their erroneous utterances (Sato \& Lyster, 2012, p. 594).

\section{Studies on the Efficacy of Recasts versus Prompts}

As noted above, few studies have compared the efficacies of recasts and prompts in eradication of learners' grammatical errors. Ellis (2007), for example, launched a study to examine the effects of metalinguistic feedback, a type of prompt, and recast on learners' accuracy by focusing on two grammatical features, namely regular past tense -ed and comparative -er. He hypothesized that the latter would be more difficult to acquire since it contains both morphology and syntax, occurs less frequently, emerges after -ed in terms of learnability, and the rule to be learned explicitly is more complex. ESL learners in a private language school formed the participants of the study who were divided into one control group and two experimental groups. While the three groups participated in one-hour communicative tasks performances, the treatment included the provision of recast for one group and metalinguistic feedback for another one and control group received no CF. Results of the study revealed that the provision of metalinguistic feedback was more effective for the acquisition of comparative adjective than past tense and those who received recast showed no significant improvement over the control group on the two grammatical features.

Lyster (2004) examined the effects of FFI and CF on French immersion students' acquisition of grammatical gender. While FFI was provided for three experimental groups, each group was distinguished from the other in terms of whether oral CF (recast versus prompts) was provided or not. The fourth group was the control group that received neither FFI nor CF. The findings revealed that the participants of FFI-prompt group significantly outperformed the participants of FFI-recast group in written production but not in oral production. Overall, of the eight posttest measures, the performances of FFI-prompt group were significantly better than those of control group in all eight measures, FFI- 
recast group outperformed the control group in five measures and the results of FFI-only group were significantly better than those of control group in four posttests.

Sato \& Lyster (2012) conducted a quasi-experimental study to examine the effects of peer interaction and CF on second language development when learners would be trained to provide CF (recast versus prompts) for each other. Building on Levelt's (1983) perceptual theory of monitoring and the declarative-procedural model of skill-acquisition theory (Anderson, 1983, 2005; Johnson, 1996), Sato \& Lyster's (2012, p. 595) suggest that the provision of CF by teachers or peers may facilitate learners' monitoring when they cannot pinpoint or edit their own errors. That is, the provision of CF may pave the way for "comparison of the erroneous utterance (via recast), or with an opportunity to test another hypothesis (via prompts)" during interaction. Based on their findings, they argue that CF provision may correlate with both accuracy and fluency development as long as the learners would be form oriented and need to proceduralize their rule-based knowledge to access it during spontaneous production. The impact of recasts and prompts on accuracy development was revealed to be the same in this study.

Yang \& Lyster (2010) conducted a quasi-experimental study to examine the effects of recast, prompts, and no CF on regular and irregular past-tense verbs. They predicted that representational and acquisitional processes of these verbs would be different since the former verbs were rule-based and the latter ones were complex and unpredictable. The results of their study revealed that the provision of prompts were more effective for the accurate use of regular pasttense forms than that of recasts but these two types of CF had similar effects on improving accuracy in the use of irregular past-tense forms among adult EFL students in China.

\section{METHODOLOGY}

\section{A. Participants}

Participants of this study were 96 students who were selected, on the basis of their grades, out of 169 male EFL freshmen students who took the standard and valid test of CELT (Comprehensive English Language Test) at a university in northern Iran. That is, 96 students who were one standard deviation above and below the mean of the test were selected. On the basis of their performances on a picture description test, the 96 subjects were divided into three groups through matching procedure (it will be explained below).

\section{B. Instrumentation}

The instrumentation used in this study included two pretests, a treatment and a posttest. The first pretest was a general language proficiency test of CELT. The test comprised three sections: structure section containing 75 items, vocabulary section including 75 items, and reading comprehension section having 24 items. All the items were in multiple choice formats.

The second pretest was a picture description test which was devised to find the grammatical accuracy of the students' speech in terms of syntactic agreement associated with '-s inflection' and the present forms of the verb 'to be'. The pictures were selected in such a way to elicit these two types of grammatical structures. The pictures, which included three parts, for the picture description test were selected out of 6 parts through a pilot study done on 10 freshmen students whose grades were between one standard deviation above and below the mean of the CELT but did not participate in the main study. The time devoted to picture description test was around four minutes and thirty seconds, based on the pilot study. Of course, the students in the pretest were not told that they would take the same test for posttest (See appendix 1 for the picture description test). The treatment of this study included the provision of two types of CF, recast and prompts, each of which was used in one experimental class. The control group did not receive any treatment. What follows summarizes a set of procedures used in order to achieve the purpose of this study.

\section{Procedures}

The CELT was administered to 169 subjects at the very outset. The time given was 100 minutes and the correct answer for each item received one point. There was no correction for guessing. After taking the exam, each subject was rendered a grade based on his performance on the CELT. Out of these students, 96 students whose grades were between one standard deviation above and below the mean were selected.

Then, the picture description test was administered to the 96 subjects which lasted for almost four minutes and thirty seconds for each student. The obligatory occasions for the use of third person singular present tense and the present form of the verb 'to be' were 37. The criterion for giving grades to the students' performances was based on the violation of syntactic agreement associated with $-\mathrm{s}$ inflection and the present forms of the verb 'to be'. That is, each correct use of $-\mathrm{s}$ inflection or the present form of the verb 'to be' received five points.

On the basis of the students' performances on the picture description test, they were divided into three groups through matching strategy. That is, for example, the first top grade was put aside as a member of group 1, the second top grade as a member of group 2, the third top grade as a member of group 3, the fourth top grade again as a member of group 3, the fifth top grade as a member of group 2, etc. Such a strategy culminated in three sets of thirty two grades. These three groups were randomly assigned as one control group and two experimental groups. Because of some limitations it was not possible to tape record students' performances in the pretest and posttest and, as a result, each student's performance was rated unobtrusively as he described the pictures and the errors were ticked on a paper. The 
procedure for rating was quite objective since each violation of syntactic agreement associated with $-\mathrm{s}$ inflection or the present forms of the verb to be was considered as one error.

The research project was conducted in conversational classes held in the university as extracurricular activity where Interchange 1 ( $3^{\text {rd }}$ Edition) was used as the textbook. As part of class activities, three picture stories were selected from a book entitled 'Sequences: Picture Stories for ESL' (Julich \& Chabot, 2006) and each was worked with the students for 20 minutes in three separate sessions during the course so that students would be familiar with how to do picture description tasks. The second researcher in this study was the teacher for the three groups of students.

The treatment included the provision of two types of CF to experimental groups and the control group did not receive any treatment. That is, recast, conversational and didactic techniques, was provided to one experimental group and prompts, all types except paralinguistic signal, to the other one (see table 1). While students were involved in oral practices with their peers or the teacher, their erroneous utterances in recast group were reformulated minus the errors even if no communication problem had been arisen. For example, if a student said "*He comb his hair", the teacher would say, "He combs his hair". The following example, taken from the study, illustrates the provision of recast as a reaction to a student' erroneous use of past tense:

Student: * My father go to work at 7 o'clock.

Teacher: So he goes to work at 7 o'clock. (with an approval sign)

Student: Yes, he goes to work at 7 o'clock.

Four techniques of 'repetition', 'clarification request', metalinguistic clue' and 'elicitation' were used separately or in combination to feedback on students' erroneous utterances in prompts group. While the common features of all these four prompts are withholding correct forms and signs of approval along with pushing learners to self-repair their own erroneous forms, the provisions of correct forms and approval signs form the distinguishing features of recast. The examples that follow taken from the data of the present study illustrate the application of four techniques of prompts.

Repetition: teacher repeats the student's ill-formed utterance, adjusting intonation to highlight the error.

Student: * John play football.

Teacher: * John PLAY football? (rising intonation on the word 'play')

Student: John plays football.

Clarification requests: clarification request indicates to the students either that their message has not been understood by the teacher or that the utterance is ill-formed in some way and that a repetition or a reformulation is required. A clarification request includes phrases such as "pardon?" and "I don't understand".

Student: * My neighborhood are very crowded.

Teacher: Pardon?

Student: My neighborhood is very crowded.

Metalinguistic clues: teacher provides comments, information, or questions related to the well-formedness of the student utterance, without explicitly providing the correct form. Metalinguistic comments generally indicate that there is an error somewhere. For example, "Can you find your error?" Metalinguistic information generally provides either some grammatical metalanguage which refers to the nature of the error (e.g. 'The subject noun is singular') or a word definition in the case of lexical errors. Metalinguistic questions also point to the nature of the error but attempt to elicit the information from the student (e.g. 'Is the subject plural?').

Teacher: Look at the picture and say what you see.

Student: There is a woman.

Teacher: Can you tell me what the woman looks like?

Student: * She is tall and her hairs are long.

Teacher: HIIRS? This is an uncountable noun.

Student: So it cannot take plural 's'. Ok. Her hair is long.

Teacher: That's right.

Elicitation: teachers directly elicit a reformulation from the students by asking questions. First, teachers use various questions to elicit correct forms. For example, "How do you say Gorbeh (cat) in English?" Second, teachers elicit completion of their own utterance by strategically pausing to allow students to 'fill in the blank.' For example, "It is called a ... ." The following example was taken from this study:

Student 1: * My brother studies physic.

Teacher: We call this field of study Fizik in Farsi, but in English it is called ...? (the teacher pauses and lets the student to self-correct himself)

Student 2: Physics. (peer correction)

Teacher: That's right.

Student 1: Ok. *My brother studies physics and I like these fields of study.

Teacher: THESE FIELDS of study? Look! that 's' at the end of the word "physics" does not make it plural. This is an uncountable noun. (Metalinguistic prompt)

Student 1: I see. I like this field of study. 
Finally, at the end of the term which lasted for 12 sessions, one session a week, the same picture description test used in the pretest was administered as the posttest and each student's performance was rated manually in an unobtrusive manner. (in the pretest the students were not told that they would take the same test at the end of the term)

\section{Data Analysis}

A number of statistical procedures were used in this study. First, to find the homogeneity of the 96 subjects who formed the control and two experimental groups, the one-way ANOVA technique was used. To do this, subjects' grades on the picture description test in the pretest were used. Next, another one-way ANOVA was used to find the effectiveness of the treatments in the posttest. Since the F ratio was significantly higher than the F critical, a Scheffe test was used to find the exact location of the difference. Then, three paired $t$-tests were used to compare the mean of each group in the pretest with that of the posttest. Finally, a two-way ANOVA was used to find the main effects of the method. The data of pretest, which functioned as the covariates, entered in the SPSS (version 16) after the main effects, which were the method.

\section{RESUlts}

This study was conducted to find an appropriate answer to the following research question: Is recasting a more effective negative feedback type than the provision of prompts for the eradication of grammatical errors of the Iranian EFL students' speech? In order to do so, several statistical procedures were utilized the results of which are presented in the following sections:

\section{A. Analysis 1}

A one-way ANOVA was used to find whether the control and two experimental groups were homogenous after the matching procedure was utilized. To do so, their grades in the picture description test of pretest were used. The results are presented in Table 2.

TABLE 2.

ONE-WAY ANOVA FOR PERFORMANCE ON THE PICTURE DESCRIPTION TEST IN THE PRETEST

\begin{tabular}{|l|l|l|l|l|l|}
\hline Source & D.F. & SS & MS & F ratio & F critical \\
\hline Between group & 2 & 18.7500 & 9.3750 & .0104 & 3.09 \\
\hline Within group & 93 & 84121.8750 & 904.5363 & \multicolumn{1}{l|}{} \\
\cline { 2 - 4 } & \multicolumn{4}{|c}{ P<.05 }
\end{tabular}

As the results of the one-way ANOVA show, F ratio does not exceed the F critical value. This implies that there is no significant difference among the control and two experimental groups and, as a result, the three groups are homogeneous.

\section{B. Analysis 2}

A one-way ANOVA was conducted to see how the control and two experimental groups performed in the posttest and whether the differences among their means were significant. The results are presented in Table 3.

TABLE 3.

ONE-WAY ANOVA FOR PERFORMANCE ON THE PICTURE DESCRIPTION TEST IN THE POSTTEST

\begin{tabular}{|l|l|l|l|l|l|}
\hline Source & D.F. & SS & MS & F ratio & F critical \\
\hline Between group & 2 & 40252.0833 & 20126.041 & 30.2883 & 4.62 \\
\hline Within group & 93 & 61796.8750 & 664.4825 & \multicolumn{1}{|c}{} \\
\cline { 1 - 3 }
\end{tabular}

As the results of the one-way ANOVA in the table 3 show, F ratio exceeds the F critical value implying that there is a significant difference among subjects' performances on the different forms of CF. To find where this difference is located, a Scheffe test was carried out the results of which were presented in Table 4.

TABLE 4.

SCHEFFE TEST WITH SIGNIFICANT LEVEL .05 FOR THE PERFORMANCE ON THE PICTURE DESCRIPTION TEST IN THE POSTTEST

\begin{tabular}{|l|l|l|l|l|}
\cline { 3 - 5 } \multicolumn{2}{c|}{ Group } \\
\hline Mean & Method & 1 & 2 & 3 \\
\hline 103.7500 & Group 1 (Control) & & & \\
\hline 132.1875 & Group 2 (Recast) & $*$ & & \\
\hline 153.7500 & Group 3 (Prompts) & $*$ & $*$ & \\
\hline
\end{tabular}

(*) Indicates significant differences which are shown in the lower triangle

Table 4 shows that these differences lay between group 1 (control group) and group 2 (recast group), group 1 and group 3 (prompts group), and group 2 and group 3. In other words, recast group and prompts group performed better than control group and prompts group performed the best of all.

C. Analysis 3 
To see how each group performed in its pretest and posttest, paired t-test technique was utilized to compare the means of each group in its pretest and posttest performances. The results were presented in Tables 5, 6, and 7 .

TABLE 5.

T-TEST FOR PAIRED SAMPLES OF CONTROL GROUP

\begin{tabular}{|l|l|l|l|l|l|l|}
\hline Variable & Mean & SD & t-value & DF & 2-tail Sig. & t-critical \\
\hline Posttest control & 103.7500 & 28.141 & .18 & 31 & .855 & 2.042 \\
\hline Pretest control & 102.8125 & 30.132 & \multicolumn{7}{l}{ con CI $(-9.410,11.285)$} & p $<.05$
\end{tabular}

The results in the Table 5 indicate that the $\mathrm{t}-\mathrm{value}$ does not exceed the $\mathrm{t}$-critical. Therefore, there is no significant difference between performance of the control group in the pretest and the posttest.

TABLE 6.

T-TEST FOR PAIRED SAMPLES OF RECAST GROUP

\begin{tabular}{|l|l|l|l|l|l|l|}
\hline Variable & Mean & SD & t-value & DF & 2-tail Sig. & t-critical \\
\hline Posttest recast & 132.1875 & 22.716 & 4.56 & 31 & .000 & 2.042 \\
\hline Pretest recast & 101.8750 & 30.074 & p \\
\hline
\end{tabular}

The results in the Table 6 show that the $\mathrm{t}-$ value exceeds the $\mathrm{t}-$ critical implying that the Recast group performed significantly better in the posttest than in pretest.

TABLE 7.

T-TEST FOR PAIRED SAMPLES OF PROMPTS GROUP

\begin{tabular}{|l|l|l|l|l|l|l|}
\hline Variable & Mean & SD & t-value & DF & 2-tail Sig. & t-critical \\
\hline Posttest prompts & 153.7500 & 26.182 & 7.23 & 31 & .000 & 2.042 \\
\hline Pretest prompts & 101.8750 & 30.020 \\
\multicolumn{7}{|c|}{$95 \%$ CI (37.243, 66.507) }
\end{tabular}

As the results in the Table 7 show, the $\mathrm{t}-$ value exceeds the $\mathrm{t}$-critical implying that the prompts group performed significantly better in the posttest.

\section{Analysis 4}

To get satisfactory results, a two-way ANOVA was used to find the main effects of the method. The data of the pretest which functioned as the covariates entered in the SPSS after the main effects. The results were presented in the Table 8.

TABLE 8.

TWO-WAY ANOVA FOR THE PRETEST AND POSTTEST

\begin{tabular}{|c|c|c|c|c|c|c|}
\hline Source of variance & Sum of square & DF & Mean square & $\mathrm{F}$ & Sig of F & F critical \\
\hline Main effects & 40252.083 & 2 & 20126.042 & 30.935 & .000 & 3.09 \\
\hline Method & 40252.083 & 2 & 20126.042 & 30.935 & .000 & 3.09 \\
\hline Covariates & 1941.949 & 1 & 1941.949 & 2.985 & .087 & 3.94 \\
\hline Pretest & 1941.949 & 1 & 1941.949 & 2.985 & .087 & 3.94 \\
\hline Explained & 42194.032 & 3 & 14064.677 & 21.618 & .000 & 2.70 \\
\hline Residual & 59854.926 & 92 & 650.597 & & & \\
\hline Total & 102048.958 & 95 & 1074.200 & & & \\
\hline
\end{tabular}

The results in the Table 8 show that the F ratios of the main effects, which is the method, exceeds the $F$ critical values, while the covariates, which is pretest, does not. The F ratio of main effects, 30.935 , is quite pure, since the effect of pretest is not involved in it.

Therefore, the results of the above-mentioned analyses reveal that the hypothesis formulated in this study can be rejected with caution. That is, prompts seem to be more suitable for the eradication of grammatical errors in the students' speech than recast.

\section{DISCUSSION}

The purpose of this study was to investigate whether corrective feedback (CF) could enhance grammatical accuracy in the learners' speech; and if it could, which type of CF is more effective than the other one for the eradication of morphosyntactic errors in learners' speech. The results of the study indicated that negative feedback in general and prompts in particular may have a facilitative role in foreign language acquisition. However, as the students in recast group, who were rarely provided the chance to self-repair, achieved fewer gains in the posttest, the prompts group's enhanced performance in the posttest might signify the value of provision of frequent opportunities to the learners to initiate self-repairs so that they can boost their control over those internalized forms that have not been proceduralized. Although the provision of CF can result in uptake, defined as a student responses to CF (Lyster \& Ranta, 1997) which might be a sign of noticing (Mackey et al., 2000), it seems that the value of uptake after the provision of prompts is not 
the same as that of recast since the provision of recast might result in repetition. As Panova and Lyster (2002) suggest, "uptake consisting of a repetition may not have much to contribute to L2 development, because of its redundancy in an error treatment sequence where the repair is both initiated and completed by the teacher within a single move" (p. 579).

Some studies have revealed the inefficacy of morophosyntactic recasting in comparison with phonological and lexical recasts (see for example Mackey et al., 2000; Carpenter et al., 2006). However, Carpenter et al. (2006) threw doubt on Lyster's (2004) results, which indicated that prompts are more effective than recasts for eradication of morphosyntactic errors, on the ground that he obtained his findings in immersion programs and they called for replication of such study in other settings. Based on the results of this study, one reason for the effectiveness of prompts over recasts in reducing the grammatical errors might be the relative length of prompts. The following two examples, the first one taken from the classroom treatment in recast group and the second one from that of prompts group, reveal that the CF in the prompts group is longer than the one in recast group (six words as opposed to one) and, as a result, it might have been better noticed. While each learner in these two cases repairs the erroneous word, the student's reactive words to the CF in the second example (i.e., "ah yes") indicate that his declarative knowledge has been tapped by the $\mathrm{CF}$ and it seems that his awareness of the gap between what he knows and what he can say is much more profound in comparison with the student in recast group who might have just repeated the correct word without any awareness. While the provision of prompts, as illustrated in (2), can be considered as time-consuming undertaking which might block the flow of communication, Rod Ellis et al. (2009, p. 329) suggest that metalinguistic feedback does not intrude unduly in the communicative flow of the activity. It constitutes a brief time-out from communicating, which allows the learner to focus explicitly but briefly on form. The effectiveness of the metalinguistic feedback, therefore, may derive in part from the high level of awareness it generates and in part from the fact that it is embedded in a communicative context.

(1) Student: Ali go to the library $=$

Teacher: $=$ Goes

Student: goes to the library.

(2) Student: Ali need a book =

Teacher: $=$ need a book $>$ Ali is a third person pronoun

Student: ah yes, Ali needs a book.

Key: = signifies overlapping comment; > signifies rising intonation

In conducting any research project, there are a few limitations that might contaminate the results of the study. First, only male students formed the participants of this study. Therefore, one can also examine the impact of CF types on the grammatical accuracy of the female as well as male students' speech and compare their performances in order to find out whether their performances are significantly different or not. Second, since third person singular present tense and the present forms of the verb 'to be' delimited the examination of grammatical accuracy in this study, determining the efficacy of various forms of $\mathrm{CF}$ for other grammatical points might be promising. Third, no delayed posttest was included in this study to compare its results with that of immediate posttest. It would be of interest to determine how long any effects of CF types persisted over a longer time frame using an appropriate longer term measures. Fourth, a picture description test was used to verify the efficacy of CF types. It seems that the incorporation of some written measures, such as cloze test, might fortify the results of the study.

\section{CONCLUSION}

The results of the present study revealed that (a) the provision of prompts and recast were significantly more effective than no CF for boosting the grammatical accuracy of Iranian EFL learners' speech, and (b) students receiving prompts significantly outperformed the recast group. It seems that the provision of prompts, which not only draws language learners' attention to problematic areas but also might make them self-correct their malformed output, provides appropriate opportunities for learners who have relevant declarative knowledge to proceduralize their knowledge of grammatical features. The relative inferiority of morphosyntactic recasting might be ascribed to the ambiguity it creates for the learners in such a way that they might not be certain whether the classroom teacher's comments were a sign of approval or a negative feedback (Lyster, 2004).

While this study focused on two grammatical structures, future research studies are needed to examine the relative impact of CF types on other grammatical features. However, the results of such studies must be considered with caution since they might not be straightforward solutions to be readily applied in any classroom settings. Many questions regarding the practice of CF might occupy student teachers' minds in any language pedagogical courses. Nonetheless the answers to these questions are too complex to be formulated as some simple remedies. Ellis (2012), for example, chops this onion and underscores individual learner factors, such as the extent of their language proficiency, working memories, phonetic coding abilities or language analytic abilities, as mediating factors that might affect the choice of CF types. By the same token, Yoshida (2008) reports a mismatch between teachers' choice and learners' preference of CF types in Japanese-as-a-foreign-language classrooms. That is, while teachers of the study preferred to provide more recasts to language learners because of being aware of learners' cognitive styles and shortage of class time, the students yearned for the chance to self-correct. While one should accept that the quest for the Holy Grail of the best CF type which functions as one-size-fits-all classroom settings might come to naught, future well-rounded research studies on 
$\mathrm{CF}$, preferably action research studies to be launched by language practitioners in their own specific socio-cultural settings, might shed more light at this precious but multifaceted pedagogical procedure.

\section{APPendix. Picture Description TAsks for Pretest AND Posttest}

1. Compare and contrast picture A with picture B.

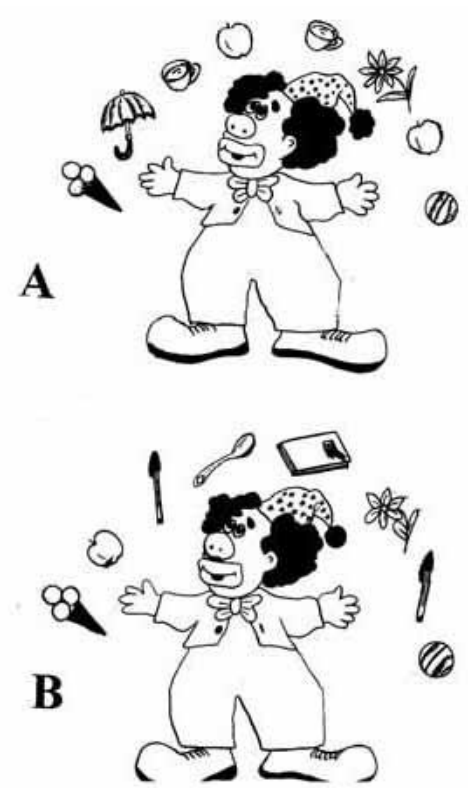

2. Compare Peter and Mary's life with that of John.

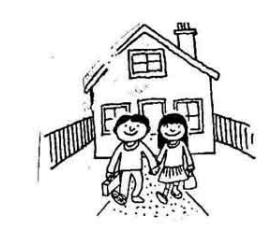

Peter and Mary

Oxford
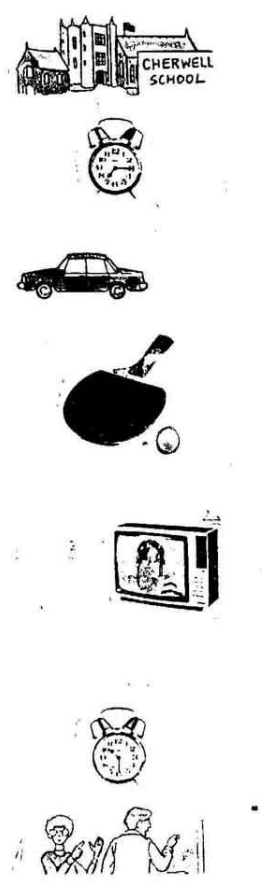
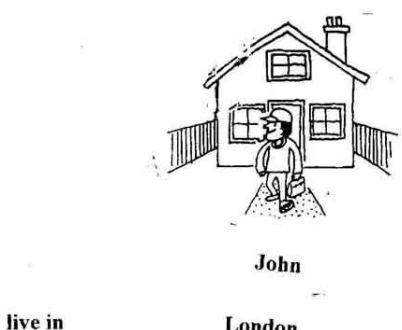

go to

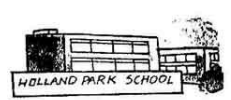

get up at

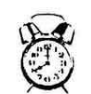

go to school by

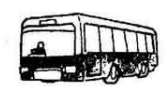

play
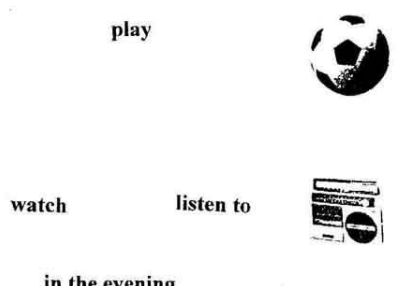

go to bed at

(to be) ...... going to

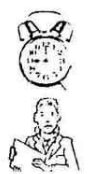


3. Describe what John does in the morning before going to work.

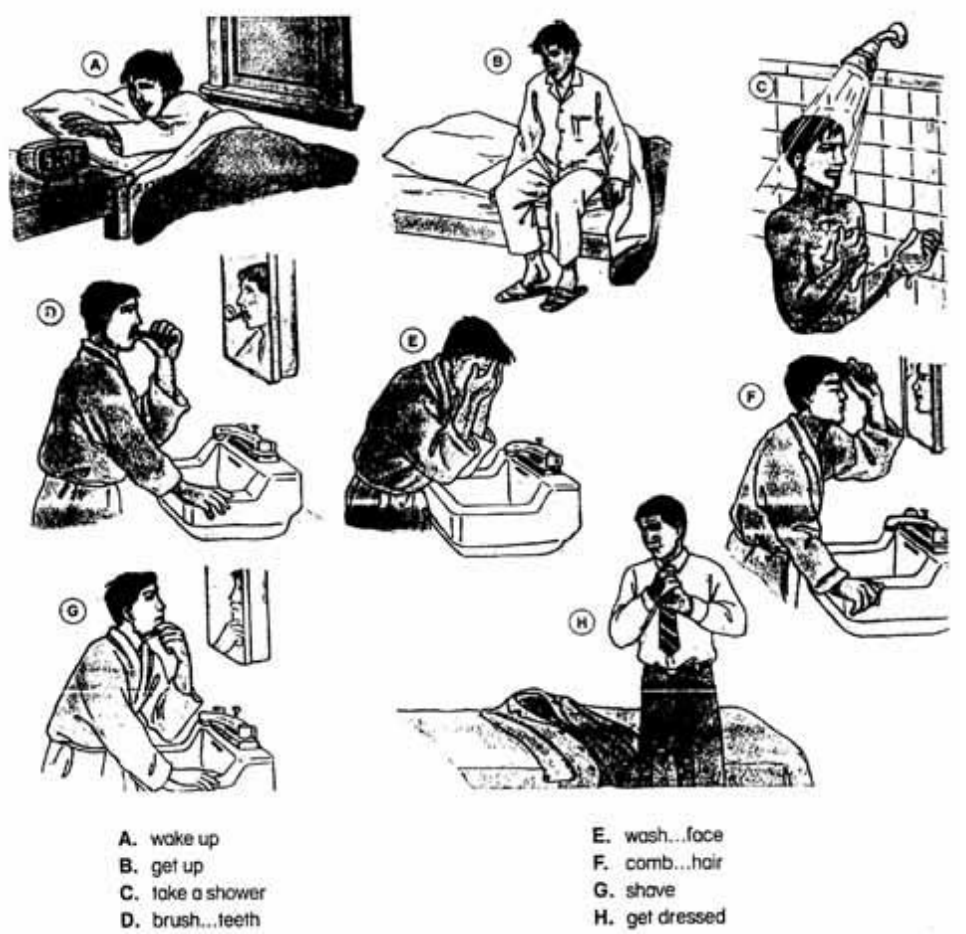

REFERENCES

[1] Ammar, A., \& Spada, N. (2006). One size fits all? Recasts, prompts and L2 learning. Studies in Second Language Acquisition, $28,543-574$.

[2] Anderson, J. (1983). The architecture of cognition. Cambridge, MA: Harvard University Press.

[3] Anderson, J. (2005). Cognitive psychology and its implications (6th edn.). New York: Worth.

[4] Carpenter, H., Jeon S., MacGregor D. \& Mackey A. (2006). Recasts as repetitions: Learners' interpretations of native speaker responses. Studies in Second Language Acquisition, 28.2, 209-236.

[5] DeKeyser, R. (1998). Beyond focus on form: Cognitive perspectives on learning and practicing second language grammar. In C. Doughty \& J. Williams (eds.), Focus on form in classroom second language acquisition. New York: Cambridge University Press, 42-63.

[6] DeKeyser, R. (2001). Automaticity and automatization. In P. Robinson (Ed.), Cognition and second language instruction. New York: Cambridge University Press, 125-151.

[7] Doughty, C. (2001). Cognitive underpinnings of focus on form. In P. Robinson (Ed.), Cognition and second language instruction. New York: Cambridge University Press, 206-257.

[8] Doughty, C., \& Varela, E. (1998). Communicative focus on form. In C. Doughty \& J. Williams (eds.), Focus on form in classroom second language acquisition. New York: Cambridge University Press, 114-138.

[9] Doughty, C., \& Williams, J. (1998). Pedagogical choices in focus on form. In C. Doughty \& J. Williams (eds.), Focus on form in classroom second language acquisition. New York: Cambridge University Press, 197-261.

[10] Ellis, R. (1994). A theory of instructed second language acquisition. In N. Ellis (ed.), Implicit and explicit language learning. London: Academic Press, 79-114.

[11] Ellis, R. (1997). SLA research and language teaching. Oxford: Oxford University Press.

[12] Ellis, R. (2007). The differential effects of corrective feedback on two grammatical structures. In A. Mackey (ed.), Conversational interaction in second language acquisition: A collection of empirical studies. Oxford: Oxford University Press, $339-360$.

[13] Ellis, R., Basturkmen, H., \& Loewen, S. (2001). Learner uptake in communicative ESL lessons. Language Learning, 51, 281318.

[14] Ellis, R., Loewen, S., \& Erlam R. (2009). Implicit and Explicit Corrective Feedback and the Acquisition of L2 Grammar. In R. Ellis, S. Loewen, C. Elder, R. Erlam, J. Philp \& H. Reinders (eds.), Implicit and Explicit Knowledge in Second Language Learning, Testing and Teaching. Bristle, UK: Multilingual Matters, 303-332.

[15] Ellis, R., \& Sheen, Y. (2006). Reexamining the role of recasts in second language acquisition. Studies in Second Language Acquisition, 28, 575-600.

[16] Erlam, R. \& S. Loewen (2010). Implicit and explicit recasts in L2 oral French interaction. The Canadian Modern Language Review, 67.4, 877-905. 
[17] Han, Z. (2008). On the role of meaning in focus on form. In Z. Han (ed.), Understanding second language process. Clevedon, UK: Multilingual Matters, 45-79.

[18] Harley, B. \& Swain M. (1984). The interlanguage of immersion students and its implications for second language teaching. In A. Davies, C. Criper, and A. Howatt (eds.), Interlanguage. Edinburgh: Edinburgh University Press, 291-311.

[19] Johnson, K. (1996). Language teaching and skill learning. Oxford: Blackwell.

[20] Julich, J. \& Chabot, J. F. (2006). Sequences picture stories for ESL. Ontario: Full Blast Productions.

[21] Krashen, S. (1982). Principles and Practice in Second Language Acquisition. New York: Pergamon Press.

[22] Levelt, W. (1983). Monitoring and self-repair in speech. Cognition 14.1, 41-104.

[23] Lightbown, P. \& Spada N. (1990). Focus-on-form and corrective feedback in communicative language teaching: Effects on second language learning. Studies in Second Language Acquisition, 12, 429-448.

[24] Long, M. (1983). Native speaker/non-native speaker conversation and the negotiation of comprehensible input. Applied Linguistics, 4, 126-41.

[25] Long, M. (1991). Focus on form: A design feature in language teaching methodology. In K. de Bot, R. Ginsberg, and C. Kramsch (eds.) Foreign Language Research in Cross-Cultural Perspective. Amsterdam/Philadelphia: John Benjamins.

[26] Long, M. (1996). The role of the linguistic environment in second language acquisition. In W. Ritchie \& T. Bhatia (eds.), Handbook of second language acquisition. San Diego, CA: Academic Press, 413-468.

[27] Long, M., \& Robinson, P. (1998). Focus on form: Theory, research, and practice. In C. Doughty \& J. Williams (eds.), Focus on form in classroom second language acquisition. New York: Cambridge University Press, 15-41.

[28] Lyster, R. \& Ranta L. (1997). Corrective feedback and learner uptake: Negotiation of form in communicative classrooms. Studies in Second Language Acquisition, 19.1, 37-66.

[29] Lyster, R. (1998). Recasts, repetition, and ambiguity in L2 classroom discourse. Studies in Second Language Acquisition, 20, $51-81$.

[30] Lyster, R. (2004). Differential effects of prompts and recasts in form-focused instruction. Studies in Second Language Acquisition, 26, 399-432.

[31] Lyster, R., \& Mori, H. (2006). Interactional feedback and instructional counterbalance. Studies in Second Language Acquisition, $28,269-300$.

[32] Lyster, R., Saito, K., \& Sato, M. (2013). Oral corrective feedback in second language classrooms. Language Teaching, 46.1, 140.

[33] Mackey, A., Gass, S. M., \& McDonough, K. (2000). How do learners perceive interactional feedback? Studies in Second Language Acquisition, 22, 471-497.

[34] McDonough, K. (2005). Identifying the impact of negative feedback and learners' responses on ESL question development. Studies in Second Language Acquisition, 27, 79-103.

[35] McLaughlin, B. (1987). Theories of Second-Language Learning. London: Edward Arnold.

[36] Musumeci, D. (1996). Teacher-learner negotiation in content-based instruction: Communication at cross-purposes? Applied Linguistics, 17, 286-325.

[37] Nicholas, H., Lightbown, P., \& Spada, N. (2001). Recasts as feedback to language learners. Language Learning, 51, 719-758.

[38] Panova, I., \& Lyster, R. (2002). Patterns of feedback and uptake in an adult ESL classroom. TESOL Quarterly, 36, 573-595.

[39] Pica, T. (2002). Subject-matter content: How does it assist the interactional needs of classroom language learners? Modern Language Journal, 86, 1-19.

[40] Sato, M. \& Lyster, R. (2012). Peer interaction and corrective feedback for accuracy and fluency development: Monitoring, practice, and proceduralization. Studies in Second Language Acquisition 34.4, 591-626.

[41] Schmidt, R. (1990). The role of consciousness in second language learning. Applied Linguistics, 11.2, 129-158.

[42] Sheen, Y. (2006). Exploring the relationship between characteristics of recasts and learner uptake. Language Teaching Research, 8, 361-392.

[43] Sheen, Y. (2011). Corrective feedback, individual differences and second language learning. New York: Springer.

[44] Sheen, Y. \& Ellis R. (2011). Corrective feedback in language teaching. In E. Hinkel (ed.), Handbook of research in second language teaching and learning, (vol. 2). New York: Routledge, 593-610.

[45] Spada, N. (2013). Corrective feedback (oral). In P. Robinson (ed.), The Routledge Encyclopedia of Second Language Acquisition. New York: Routledge, 139-142.

[46] Swain, M. (1985). Communicative competence: Some roles of comprehensible input and comprehensible output in its development. In S. Gass \& C. Madden (eds.), Input in second language acquisition. Rowley, MA: Newbury House, $235-253$.

[47] Tomasello, M., \& Herron, C. (1989). Feedback for language transfer errors: The Garden Path technique. Studies in Second Language Acquisition, 11, 385-395.

[48] VanPatten, B. \& Benati A. G. (2010). Key Terms in Second Language Acquisition. London: Continuum.

[49] White, L. (1987). Against comprehensible input: The input hypothesis and the development of second language competence. Applied Linguistics, 8, 95-110.

[50] Williams, J. (2005). Form-focused instruction. In E. Hinkel (ed.), Handbook of research in second language teaching and learning. Mahwah, NJ: Lawrence Erlbaum Associates, 671-691.

[51] Yang, Y. \& Lyster R. (2010). Effects of form-focused practice and feedback on Chinese EFL learners' acquisition of regular and irregular past tense forms. Studies in Second Language Acquisition, 32.2, 235-263.

[52] Yoshida, R. (2008b). Teachers' choice and learners' preference of corrective-feedback types. Language Awareness, 17.1, 7893.

Azar Hosseini Fatemi was born in 1951 in Mashhad, Iran. She got her BA degree in English Language and Literature from Ferdowsi University of Mashhad, Iran. She has received MA degree in TEFL from New Mexico, State University, USA in 1980, and 
Ph.D. degree from Panjab University, India. Her field of interests is research, teaching and learning a second language, and sociolinguistics

She is an ASSOCIATE PROFESSOR of TEFL at Ferdowsi University of Mashhad, Iran. She has 29 years of teaching experience at university level. In addition, she is the HEAD of ENGLISH DEPARTMENT at Ferdowsi University of Mashhad, Iran. She has published more than 20 articles in different journal. Some of her articles are as follows: Azar Hosseini Fatemi. The Predictive Power of Vocabulary Breadth \& Depth, and Syntactic Knowledge in Reading Comprehension Performance of Iranian Advanced EFL Students., Ferdowsi Review, Volume (2), 2012-11, Pages 3-22. Azar Hosseini Fatemi, Reza Pishghadam, arezoo asghari, Attribution Theory and Personality Traits among EFL Learners , International Journal of Linguistics , Volume ( 4 ), 2012-6, Pages 229-243. Azar Hosseini Fatemi, On the alleged relationship between LOC, L2 Reading comprehension, and use of language learning strategies, Ferdowsi Review, Volume (1), 2010-11, Pages 21-47.

Dr. Hosseini Fatemi is the executive manager and a member of editorial board of "Ferdowsi Review, An Iranian Journal of TESOL, Literature and Translation Studies".

Nazar Ali Harati was born in 1969 in Ghoochan, Iran. He got his BA degree in English Language and Literature from Ferdowsi University of Mashhad, Iran. He received his MA degree in TEFL from Iran University of Science and Technology and he is currently a Ph.D. candidate of TEFL at Ferdowsi University of Mashhad, International Branch, Mashhad-Iran. His areas of interest include second language acquisition, discourse analysis and academic writing. 